\title{
Acta
Biochimica
Polonica
}

Vol. 46 No. $4 / 1999$

919-927

QUARTERLY

\section{Kinetic studies on the oxidation of nitrite by horseradish peroxidase and lactoperoxidase $^{\oplus}$}

\author{
Lidia Gębicka ${ }^{\circledR}$
}

Institute of Applied Radiation Chemistry, Technical University of Eódż, W. Wróblewskiego 15, 93-590 Eódź, Poland

Received: 14 October, 1999

Key words: horseradish peroxidase, lactoperoxidase, nitrite, stopped-flow

The reaction of nitrite $\left(\mathrm{NO}_{2}^{-}\right)$with horseradish peroxidase and lactoperoxidase was studied. Sequential mixing stopped-flow measurements gave the following values for the rate constants of the reaction of nitrite with compounds II (oxoferryl heme intermediates) of horseradish peroxidase and lactoperoxidase at $\mathrm{pH} 7.0,13.3 \pm 0.07 \mathrm{~mol}^{-1}$ $\mathrm{dm}^{3} \mathrm{~s}^{-1}$ and $3.5 \pm 0.05 \cdot 10^{4} \mathrm{~mol}^{-1} \mathrm{dm}^{3} \mathrm{~s}^{-1}$, respectively. Nitrite, at neutral $\mathrm{pH}$, influenced measurements of activity of lactoperoxidase with typical substrates like 2,2'-azino-bis[ethyl-benzothiazoline-(6)-sulphonic acid] (ABTS), guaiacol or thiocyanate (SCN). The rate of ABTS and guaiacol oxidation increased linearly with nitrite concentration up to $2.5-5 \mathrm{mmol} \mathrm{dm}^{-3}$. On the other hand, two-electron $\mathrm{SCN}^{-}$ oxidation was inhibited in the presence of nitrite. Thus, nitrite competed with the investigated substrates of lactoperoxidase. The intermediate, most probably nitrogen dioxide $\left(\mathrm{NO}_{2}\right.$ ), reacted more rapidly with ABTS or guaiacol than did lactoperoxidase compound II. It did not, however, effectively oxidize $\mathrm{SCN}^{-}$to $\mathrm{OSCN}^{-}$. $\mathrm{NO}_{2}^{-}$did not influence the activity measurements of horseradish peroxidase by ABTS or guaiacol method.

The heme-containing peroxidases catalyze one-electron oxidation of a wide range of substrates with concomitant reduction of peroxides:

Peroxidase $+\mathrm{H}_{2} \mathrm{O}_{2} \rightarrow$ Compound $\mathrm{I}+\mathrm{H}_{2} \mathrm{O}$ (1)

Compound I $+\mathrm{SH} \rightarrow$ Compound II $+\mathrm{S}^{\bullet}$
Compound II $+\mathrm{SH} \rightarrow$ Peroxidase $+\mathrm{S}^{\bullet}$

where compound I is an oxoferryl porphyrin $\pi$-cation radical, $\mathrm{Fe}(\mathrm{IV})=\mathrm{O}\left(\mathrm{Por}^{+\bullet}\right)$, which, in the case of lactoperoxidase (LPO) (and some other peroxidases, but not horseradish peroxidase (HRP)), spontaneously transforms

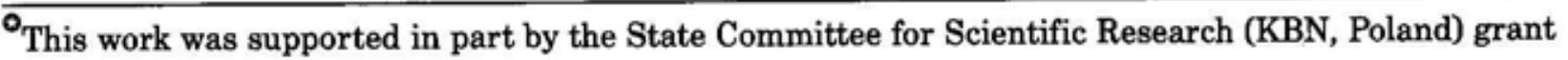
No. 3 T09A 10414

${ }^{\Xi}$ Phone: (48 42) 631 3160; Fax: (48 42) 636 0246; e-mail: lgebicka@mitr.p.lodz.pl

Abbreviations: ABTS, 2,2'-azinobis[3-ethyl-benzothiazoline-(6)-sulphonic acid]; HRP, horseradish peroxidase; LPO, lactoperoxidase; MPO, myeloperoxidase; TNB, 5-thio-2-nitrobenzoic acid.
} 
to oxoferryl protein radical, $\mathrm{Fe}(\mathrm{IV})=\mathrm{O}\left(\mathrm{R}^{\circ+}\right)$; compound II is an oxoferryl heme intermediate, $\mathrm{Fe}(\mathrm{IV})=0$; $\mathrm{SH}$ is a substrate to be oxidized. Many organic and inorganic compounds are known to serve as substrates of the peroxidase reaction [1].

Since about ten years, i.e. since the discovery that nitric oxide ( $\mathrm{NO}$ ) plays a key role in several processes, both physiological and pathophysiological, reactions of reactive nitrogen intermediates with biologically important molecules have drawn considerable interest. It is known that ${ }^{\circ} \mathrm{NO}$ is a short-living molecule the content of which is nearly 0.01-0.1 $\mu \mathrm{mol} \mathrm{dm}{ }^{-3}$ in mammalian tissues, and is significantly increased in pathophysiological processes [2]. Its autooxidation in aqueous solution is a very complex process which can be summarized as follows:

$$
4^{\bullet} \mathrm{NO}+\mathrm{O}_{2}+2 \mathrm{H}_{2} \mathrm{O} \rightarrow 4 \mathrm{H}^{+}+4 \mathrm{NO}_{2}^{-}
$$

'NO reacts rapidly with $\mathrm{O}_{2}^{-\bullet}$ to yield peroxynitrite $\left(\mathrm{ONOO}^{-}\right)$, a powerful oxidizing agent. Isomerization of peroxynitrite gives $\mathrm{NO}_{3}^{-}$, but oxidation by $\mathrm{ONOO}^{-} / \mathrm{ONOOH}^{(} \mathrm{pK}$ $=6.8$ ), results in concomitant production of $\mathrm{NO}_{2}^{-}$. Thus, nitrite is an important end product of "NO metabolism. The amount of nitrite found in healthy human subject ranges from hundreds of nanomoles in plasma up to hundreds of micromoles in saliva [3]. The level of nitrite concentration reflects not only endogenous ' $\mathrm{NO}$ production but also $\mathrm{NO}_{3}^{-} / \mathrm{NO}_{2}^{-}$ingestion [4]. It is worth noting that nitrite is also a significant contaminant in solutions of peroxynitrite synthesized on the laboratory scale. $\mathrm{NO}_{2}^{-}$may be present at millimolar concentration in peroxynitrite samples [5].

It has been shown that nitrite is oxidized by heme proteins: oxyhemoglobin [6], catalase $[7,8]$ and peroxidases $[9,10]$. More recently, it was reported that catalase was inhibited by $\mathrm{NO}_{2}^{-}$[11]. In the case of peroxidases, nitrite peroxidation occurs in the normal peroxidase cycle (reactions (1)-(3)) and the formation of nitrogen dioxide $\left({ }^{*} \mathrm{NO}_{2}\right)$ as an intermediate has been postulated [9]. The second-order rate constants for the reactions of compounds I and II of horseradish peroxidase (HRP) with nitrite increased with increasing acidity over the $\mathrm{pH}$ range 6-8 [9]. Shibata et al. [10] reported that nitrite added to a mixture containing $\mathrm{HRP}$ and $\mathrm{H}_{2} \mathrm{O}_{2}$ bleached chlorophyll and nitrated tyrosine. The optimum $\mathrm{pH}$ for bleaching of chlorophyll was 4.0. Chance [8] suggested that protonated nitrite $\left(\mathrm{HNO}_{2}, \mathrm{pK}\right.$ 3.3) could be the active form of the electron donor. Klebanoff [12] showed that myeloperoxidase (MPO) together with $\mathrm{H}_{2} \mathrm{O}_{2}$ and nitrite was toxic to $E$. coli at $\mathrm{pH} 5-7$. Recently van der Vliet et al. [3] and Sampson et al. [13] reported that HRP, LPO and MPO oxidize nitrite in the presence of $\mathrm{H}_{2} \mathrm{O}_{2}$ to catalyze nitration of tyrosine and tyrosine residues in proteins at neutral $\mathrm{pH}$. The efficiency of tyrosine nitration by investigated enzymes was found to be as follows: HRP < LPO < MPO [13].

Reszka et al. $[14,15]$ found that the presence of nitrite dramatically enhanced oxidation of some substrates by the $\mathrm{LPO} / \mathrm{H}_{2} \mathrm{O}_{2}$ system at neutral $\mathrm{pH}$. The same authors also reported that the anticancer agent, mitoxantrone, which was not metabolized by $\mathrm{LPO} / \mathrm{H}_{2} \mathrm{O}_{2}$ underwent oxidation to the biologically active quinone/diiminoquinone form of the drug by a nitrite-derived metabolite of $\mathrm{LPO} / \mathrm{H}_{2} \mathrm{O}_{2}$, presumably the ${ }^{\circ} \mathrm{NO}_{2}$ radical [16].

The aim of this work was to compare the reactivity of two peroxidases: HRP and LPO towards nitrite and to investigate the influence of the intermediate species of nitrite oxidation, most likely ${ }^{\bullet} \mathrm{NO}_{2}$, on reactions catalyzed by these enzymes.

\section{MATERIALS AND METHODS}

Horseradish peroxidase (type VI) (EC 1.11.1.7) with the purity number $R Z=A_{403} /$ $\mathrm{A}_{280}$ of 3.0 (a measure of hemin content using content of the aromatic amino acids as reference), and lactoperoxidase (EC 1.11.1.7) with $\mathrm{RZ}=\mathrm{A}_{412} / \mathrm{A}_{280}$ of 0.8 were obtained from 
Sigma and used as received. Extinction coeffcients of $1.02 \cdot 10^{5} \mathrm{~mol}^{-1} \mathrm{dm}^{3} \mathrm{~cm}^{-1}$ at $403 \mathrm{~nm}$ [17] and $1.12 \cdot 10^{5} \mathrm{~mol}^{-1} \mathrm{dm}^{3} \mathrm{~cm}^{-1}$ at $412 \mathrm{~nm}$ [18] were used for spectrophotometric determinations of HRP and LPO concentrations, respectively. Sodium nitrite $\left(\mathrm{NaNO}_{2}\right), 2,2^{\prime}$ azino-bis[ethyl-benzothiazoline-(6)-sulphonic acid] (ABTS), guaiacol, sodium thiocyanate (NaSCN), hydrogen peroxide $\left(\mathrm{H}_{2} \mathrm{O}_{2}\right) 30 \%$ were also obtained from Sigma. All other reagents were of analytical grade. All experiments were carried out at ambient temperature and at $\mathrm{pH}=7.0$. $\left(0.01 \mathrm{~mol} \mathrm{dm}^{-3}\right.$ phosphate buffer). We checked that reaction kinetics in the absence or presence of $0.1 \mathrm{~mol} \mathrm{dm}^{-3}$ $\mathrm{NaNO}_{3}$ was the same, i.e that ionic strength did not influence the reactions investigated. Nano-pure water from MilliQ (Millipore) was used throughout.

In order to determine the dissociation constant, $K_{\mathrm{D}}$, for the $\mathrm{LPO} / \mathrm{NO}_{2}^{-}$complex, difference absorption spectra (spectrum of the enzyme-substrate versus spectrum of the enzyme) were taken. Titrations were carried out by adding nitrite at concentrations of 1-50 $\mathrm{mmol} \mathrm{dm}{ }^{-3}$ to $4 \mu \mathrm{mol} \mathrm{dm}{ }^{-3} \mathrm{LPO}$ solution and to the buffer (pH 7.0) in the reference cell. $K_{\mathrm{D}}$ value was calculated according to [19].

Kinetic measurements for reactions taking place within milliseconds or seconds were performed using the SX 17 MV stopped-flow spectrofluorimeter (Applied Photophysics) with 1-cm cell. The kinetics of the reaction of compounds I or II of HRP with nitrite were studied using the sequential mixing mode of the stopped-flow apparatus. HRP solution (8 $\mu \mathrm{mol} \mathrm{dm}^{-3}$ ) placed in syringe 1 , was premixed with an equal volume of the $10 \mu \mathrm{mol} \mathrm{dm}{ }^{-3}$ $\mathrm{H}_{2} \mathrm{O}_{2}$ solution, placed in syringe 2 . After a delay of $100 \mathrm{~ms}$, the compound I formed in the aging loop was mixed with the solution containing nitrite, the concentration of which was chosen to ensure at least 10-fold excess over that of compound I. Reactions of HRP compounds I or II with nitrite were followed by changes in absorption at $412 \mathrm{~nm}$ (isosbestic point between native enzyme and compound II) or $398 \mathrm{~nm}$ (isosbestic point between compound I and compound II), respectively.

The reaction of compound II of LPO with nitrite was studied in a similar way: $4.5 \mu \mathrm{mol}$ $\mathrm{dm}^{-3}$ solution of LPO was premixed with 20 $\mu \mathrm{mol} \mathrm{dm}{ }^{-3} \mathrm{H}_{2} \mathrm{O}_{2}$ (concentrations before mixing are given). Delay time was $2 \mathrm{~s}$. We checked that after that time LPO compound I was converted to the species with absorption maximum at $430 \mathrm{~nm}$, characteristic for compound II. Now it is accepted that LPO compound I, which occurs primarily in the form of oxoferryl porphyrin $\pi$-cation radical, spontaneously transforms to the form of oxoferryl protein radical, the absorption spectrum of which is indistinguishable from that of compound II $[20,21]$. Nevertheless, reduction of compound I by an internal donor to compound II cannot be excluded. The formed LPO intermediate species (compound I in the form of protein radical and/or compound II) was then mixed with varying concentrations of nitrite (kept in at least 10-fold excess over LPO species). The rate of the decrease of absorbance at $430 \mathrm{~nm}$ was taken as a measure of the rate of the reaction of compound II with substrate. Note that, when compound I, existing in the form of a protein radical, reacts with substrate to form compound II, no changes in absorption at 430 nm should be seen.

Five determinations of rate constants were performed for each nitrite concentration and the mean values were plotted against the substrate concentration. The apparent second-order rate constants of the reactions of compounds I and II of HRP and for compound II of LPO with nitrite were calculated from the respective slopes using least-squares regression.

The kinetic measurements for the reactions occurring at a longer time-scale were performed using Hewlett-Packard 8452A diode array spectrophotometer. 


\section{RESULTS AND DISCUSSION}

It was shown that nitrite binds to heme proteins at the heme iron [22], but the concentration of nitrite as high as mmol dm $\mathrm{mm}^{-3}$ is re quired to change the absorption spectrum. Ligation of $\mathrm{NO}_{2}^{-}$to $\mathrm{HRP}$ is very sensitive to $\mathrm{pH}$. The optical spectrum of HRP in the presence of $20 \mathrm{mmol} \mathrm{dm}^{-3} \mathrm{NO}_{2}^{-}$showed no change after $13 \mathrm{~h}$ at $\mathrm{pH} 7.7$. However, at $\mathrm{pH} 5.4$, in the presence of $100 \mathrm{mmol} \mathrm{dm}{ }^{-3} \mathrm{NO}_{2}^{-}$the absorption maximum shifted to $416 \mathrm{~nm}$ within $1 \mathrm{~min}$ [22]. We have checked whether nitrite used at the concentrations required to determine the rate constants with HRP compounds I and II and in activity measurements does influence absorption spectrum of HRP. Our experiments have shown that absorption spectrum of HRP in the presence of nitrite at concentrations from $10^{-5}$ to $5 \cdot 10^{-2} \mathrm{~mol} \mathrm{dm}^{-3}$ at $\mathrm{pH}$ 7.0 remained unchanged even after several days (storing at $8^{\circ} \mathrm{C}$, measurement at room temperature). This means that under our experimental conditions most of nitrite was dissociated from the enzyme.

Spectral scans of the reaction between HRP and $\mathrm{H}_{2} \mathrm{O}_{2}$ in the presence of nitrite are shown in Fig. 1. The presence of isosbestic points during formation of compound II (Fig. 1a) and restoration of native enzyme from compound II (Fig. 1b) clearly indicate that the reaction occurs in two kinetically separated steps, involving a nitrite induced oneelectron reduction of compounds I and II, respectively. The respective second-order rate constants for the reactions of HRP compound I and II with $\mathrm{NO}_{2}^{-}$ at $\mathrm{pH} 7.0$ determined by us are $4.5 \pm 0.05$. $10^{2} \mathrm{~mol}^{-1} \mathrm{dm}^{3} \mathrm{~s}^{-1}$ and $13.3 \pm 0.07 \mathrm{~mol}^{-1} \mathrm{dm}^{3}$ $\mathrm{s}^{-1}$. These values fall into the range reported earlier [9]. In order to check whether ${ }^{\circ} \mathrm{NO}_{2}$, most probably formed as an reaction intermediate, does inactivate the enzyme, a solution containing $2 \mu \mathrm{mol} \mathrm{dm}^{-3} \mathrm{HRP}$ was incubated with $2.5 \mu \mathrm{mol} \mathrm{dm}{ }^{-3} \mathrm{H}_{2} \mathrm{O}_{2}$ and with different amounts of $\mathrm{NO}_{2}^{-}$(from $10^{-5}$ to $5 \cdot 10^{-2} \mathrm{~mol}$ $\mathrm{dm}^{-3}$ ) for the time ranging from $10 \mathrm{~min}$ to $24 \mathrm{~h}$. Then the aliquots of the solution were di- luted with the buffer in proportion 1:500 and the rates of ABTS $\left(2.5-10 \mathrm{mmol} \mathrm{dm}^{-3}\right)$ or guaiacol (2.5-10 $\left.\mathrm{mmol} \mathrm{dm}^{-3}\right)$ oxidation were measured. We found that activity of the samples incubated with $\mathrm{NO}_{2}^{-}$, irrespective of nitrite concentration and incubation time, was the same as in the absence of nitrite (not shown). We have also measured the rates of ABTS or guaiacol oxidation by adding nitrite at concentrations of $10^{-3}-5 \cdot 10^{-2} \mathrm{~mol} \mathrm{dm}^{-3}$ directly to the cuvette. Again, no change of reaction kinetics has been observed, irrespective of substrate concentration.

It has been shown that nitrite interacts with LPO [23]. The value of dissociation constant for the $\mathrm{LPO} / \mathrm{NO}_{2}^{-}$adduct, $K_{\mathrm{D}}=2.43 \mathrm{mmol}$ $\mathrm{dm}^{-3}$ at pH 5.5 was reported [24]. When nitrite concentration equals $K_{\mathrm{D}}$, half of the en-
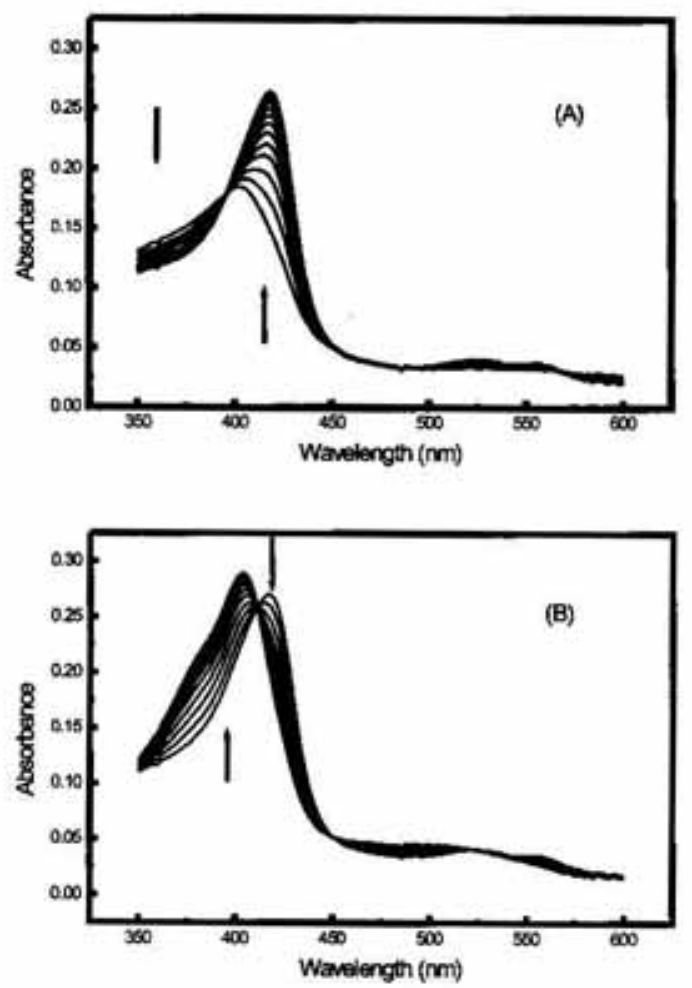

Figure 1. Absorption spectra of compound II formation (A, spectra taken every $10 \mathrm{~s}$ ) and decay $(\mathrm{B}$, spectra taken every $3 \mathrm{~min}$ ), [HRP] $=2 \mu \mathrm{mol} \mathrm{dm}^{-3}$, $\left[\mathrm{H}_{2} \mathrm{O}_{2}\right]=5 \mu \mathrm{mol} \mathrm{dm}{ }^{-3},\left[\mathrm{NaNO}_{2}\right]=5 \cdot 10^{-4} \mathrm{~mol}$ $\mathrm{dm}^{-3}, \mathbf{p H}=\mathbf{7 . 0}$.

zyme present in the solution is complexed with $\mathrm{NO}_{2}^{-}$(assuming that nitrite is in a great excess with respect to the enzyme). The ab- 
sorption maximum for the $\mathrm{LPO} / \mathrm{NO}_{2}^{-}$complex at $\mathrm{pH} 5.5$ was found at $422 \mathrm{~nm}$ [24]. We have found that $K_{\mathrm{D}}$ value for the $\mathrm{LPO} / \mathrm{NO}_{2}^{-}$complex is $20 \pm 0.5 \mathrm{mmol} \mathrm{dm}^{-3}$ at pH 7.0. This indicates that for LPO, similarly to HRP, the interaction between $\mathrm{NO}_{2}^{-}$and ferric iron is weaker at neutral $\mathrm{pH}$ than in acidic solution.

In a similar manner as in the experiments with HRP, i.e. by the method of sequential mixing, we have tried to determine the rate constant of the reaction of LPO compound I and compound II with nitrite. It is known that LPO compound I, occurring in the form of porphyrin $\pi$-cation radical is very unstable $\left(\mathrm{t}_{1 / 2} \approx 0.2 \mathrm{~s}\right)$ and spontaneously transforms to the species showing an absorption spectrum typical for compound II [25]. However, it has been suggested, that the species formed could be compound I in the oxoferryl protein radical form. In fact, it is spectroscopically indistinguishable from compound II [21]. After a delay of $50 \mathrm{~ms}$, i.e. at a time when LPO compound $\mathrm{I}$ in the form of porphyrin $\pi$-cation radical is being formed, the solution was mixed with nitrite and an increase of absorbance at $430 \mathrm{~nm}$ (maximum of compound II absorption band) was detected. Unfortunately, the spontaneous transformation of porphyrin radical form of compound I into protein radical form ( $k=3.5 \pm 0.05 \mathrm{~s}^{-1}$ (our unpublished results)), strongly disturbs observations of the reaction of compound I with nitrite and prevents precise determination of the rate constant for this reaction. The absorbance at $430 \mathrm{~nm}$ observed after LPO compound II formation is by about $30 \%$ lower in the presence of both $\mathrm{H}_{2} \mathrm{O}_{2}$ and nitrite than in the presence of $\mathrm{H}_{2} \mathrm{O}_{2}$ alone. The lowered concentration of LPO compound II is most probably due to a smaller, in comparison with HRP, difference in the rate constants for the reactions of LPO compounds I and II with nitrite. A similar observation were made by Metodiewa \& Dunford [26] who studied the reactions of LPO compounds I and II with 3-aminotriazole.

Using sequential mixing with a delay time of $2 \mathrm{~s}$ (see Materials and Methods) it was possi- ble to measure the rate constant of LPO compound II with nitrite. We obtained a value of $3.5 \cdot 10^{4} \pm 0.05 \mathrm{~mol}^{-1} \mathrm{dm}^{3} \mathrm{~s}^{-1}$ ( $\mathrm{pH} \mathrm{7.0)}$. It is three orders of magnitude higher than that for HRP.

Bactericidal activity of lactoperoxidase in vivo is connected with two-lectron oxidation of thiocyanate to hypothiocyanite anion, $\mathrm{OSCN}^{-}$(at $\mathrm{pH}$ 7.0), the formation of which may be followed spectrophotometrically at $235 \mathrm{~nm}$ [27]. The rate of thiocyanate oxidation $\left(\left[\mathrm{SCN}^{-}\right]=1 \mathrm{mmol} \mathrm{dm}^{-3}\right.$ ) by LPO in the presence of $1 \mathrm{mmol} \mathrm{dm}^{-3} \mathrm{H}_{2} \mathrm{O}_{2}$ decreased with increasing nitrite concentration and was completely inhibited when $2.5 \mathrm{mmol} \mathrm{dm}{ }^{-3}$ nitrite was present in the sample (not shown). The reported values of the rate constant of LPO compound I with $\mathrm{SCN}^{-}$at $\mathrm{pH} 7.5$ are in the range $4 \cdot 10^{4}-1.1 \cdot 10^{5} \mathrm{~mol}^{-1} \mathrm{dm}^{3} \mathrm{~s}^{-1}[28,29]$ i.e. they are comparable with the rate constant of LPO compound II with nitrite obtained by us. Note that the rate constant for the reaction of LPO compound I with nitrite estimated by us was only several times higher (also of the order of $10^{5} \mathrm{~mol}^{-1} \mathrm{dm}^{3} \mathrm{~s}^{-1}$ ). This may suggest that $\mathrm{SCN}^{-}$and $\mathrm{NO}_{2}^{-}$compete with each other for LPO compound I. The other possibility is that $\mathrm{NO}_{2}^{-}$blocks the binding site for $\mathrm{SCN}^{-}$in the enzyme. It is generally accepted that peroxidase substrates bind to the enzyme prior to the catalytic reaction. The dissociation constant, $K_{\mathrm{D}}$, for $\mathrm{LPO} / \mathrm{SCN}^{-}$complex was reported to be $20.3 \mathrm{mmol} \mathrm{dm}^{-3}$ at pH 5.5 [24] but $90 \pm 0.5 \mathrm{mmol} \mathrm{dm}^{-3}$ at pH 6.1 [30]. Nitrite ions strongly compete with $\mathrm{SCN}^{-}$in binding to the enzyme and the $K_{\mathrm{D}}$ value for the $\mathrm{LPO} / \mathrm{SCN}^{-}$complex in the presence of $\mathrm{NO}_{2}^{-}$ (at a concentration four times as high as $K_{\mathrm{D}}$ ) is $88.1 \mathrm{mmol} \mathrm{dm}^{-3}$ [24] at pH 5.5. However, as we carried out our measurements at ion concentrations lower than $K_{\mathrm{D}}$, i.e. under conditions when more than half of the amount of enzyme remained in the uncomplexed form, it seems unlikely that inhibition of $\mathrm{SCN}^{-}$oxidation by nitrite was caused by difficulties in $\mathrm{SCN}^{-}$binding to protein prior to the catalytic reaction. 
Van der Vliet et al. [3] found that the oxidation of 5-thio-2-nitrobenzoic acid (TNB) by the $\mathrm{LPO} / \mathrm{H}_{2} \mathrm{O}_{2} / \mathrm{SCN}^{-}$system was enhanced by $\mathrm{NO}_{2}^{-}$when $\left[\mathrm{NO}_{2}^{-}\right]$was two orders of magnitude lower than $\left[\mathrm{SCN}^{-}\right]$. Thus, when the ratio $\left[\mathrm{SCN}^{-}\right] /\left[\mathrm{NO}_{2}^{-}\right]=100$, the competition between those two anions with LPO compound I seems unlikely. It is possible that LPO compound $\mathrm{I}$, in addition to reacting with $\mathrm{SCN}^{-}$, is reduced to compound II by an internal donor. Compound II is unable to oxidize $\mathrm{SCN}^{-}$but can react with nitrite to produce ${ }^{\circ} \mathrm{NO}_{2}$, which in turn oxidizes TNB, additionally to $\mathrm{OSCN}^{-}$.

Incubation of a solution containing $2 \mu \mathrm{mol}$ of $\mathrm{NO}_{2}^{-}$(Fig. 2-inset). We have observed that the rate of ABTS and guaiacol oxidation increases linearly up to about $2.5-5 \mathrm{mmol} \mathrm{dm}^{-3}$ $\mathrm{NO}_{2}^{-}$. Above these concentrations, the influence of $\mathrm{NO}_{2}^{-}$becomes less and less pronounced to reach saturation at about $12 \mathrm{mmol}$ $\mathrm{dm}^{-3}$ and $20 \mathrm{mmol} \mathrm{dm}^{-3}$ nitrite, respectively, for guaiacol and ABTS. On comparing the rate constants for the reactions of LPO compound II with nitrite with those for the investigated substrates one can conclude that nitrite is able to compete with LPO substrates. The intermediate, most probably ${ }^{\circ} \mathrm{NO}_{2}$, reacts more rapidly with $\mathrm{ABTS}$ and guaiacol than does

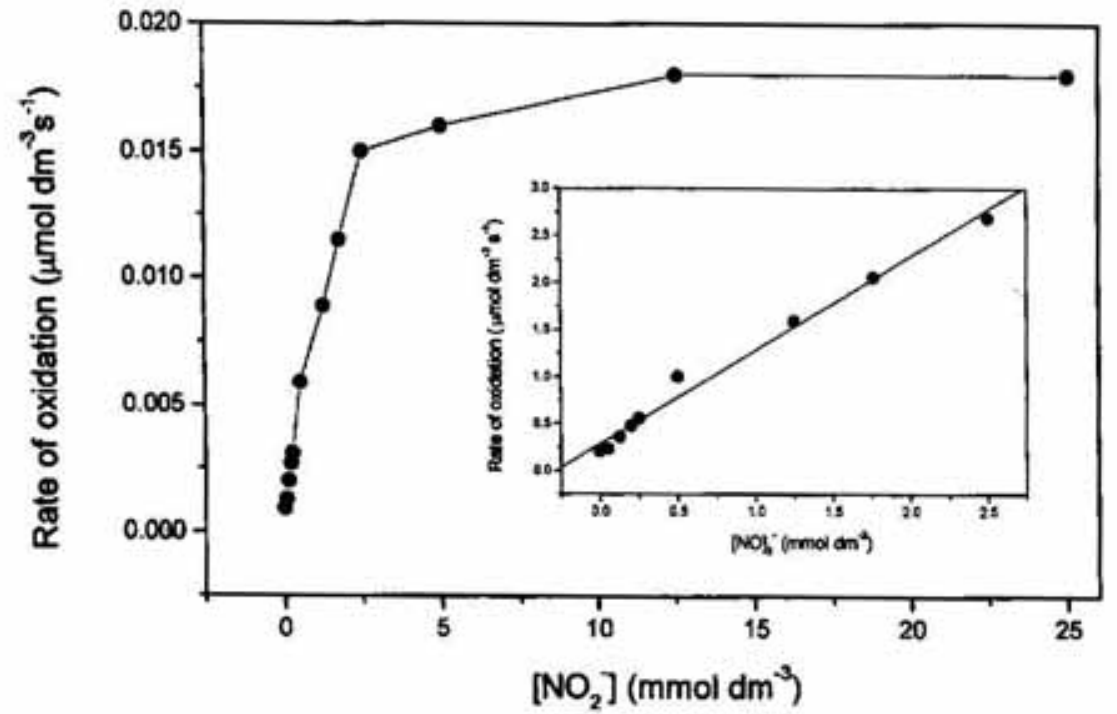

Figure 2. Influence of nitrite on LPO-catalyzed guaiacol oxidation, [LPO] $=2$ $\cdot 10^{-8} \mathrm{~mol} \mathrm{dm}^{-3},\left[\mathrm{H}_{2} \mathrm{O}_{2}\right]=$ $5 \mathrm{mmol} \mathrm{dm}^{-3}$, [guaiacol] = $5 \mathrm{mmol} \mathrm{dm}^{-3}, \mathrm{pH}=\mathbf{7 . 0}$. $\mathrm{dm}^{-3} \mathrm{LPO}, 20 \mu \mathrm{mol} \mathrm{dm}{ }^{-3} \mathrm{H}_{2} \mathrm{O}_{2}$ and nitrite at concentrations up to $0.1 \mathrm{mmol} \mathrm{dm}{ }^{-3}$ for different time intervals (from $10 \mathrm{~min}$ to $24 \mathrm{~h}$ ) followed by 500 -fold dilution of the samples and determination of activity by the ABTS method indicates that ${ }^{\circ} \mathrm{NO}_{2}$ does not inactivate LPO.

The presence of nitrite at a concentration $\geq 0.1 \mathrm{mmol} \mathrm{dm}^{-3}$ caused an increase of the rate of oxidation of ABTS (not shown) or guaiacol (Fig. 2). At $2.5 \mathrm{mmol} \mathrm{dm}$ concentration, nitrite accelerated oxidation of 2.5 $\mathrm{mmol} \mathrm{dm} \mathrm{m}^{-3} \mathrm{ABTS}$ approximately fivefold (not shown) and the oxidation of guaiacol even more efficiently. In the presence of $2.5 \mathrm{mmol}$ $\mathrm{dm}^{-3}$ nitrite, $5 \mathrm{mmol} \mathrm{dm}{ }^{-3}$ guaiacol was oxidized sixteen times faster than in the absence
LPO compound II ([31, 32] and our unpublished results), thus their oxidation in the presence of nitrite occurs faster. On the other hand, " $\mathrm{NO}_{2}$ seems to be unable to oxidize $\mathrm{SCN}^{-}$to $\mathrm{OSCN}^{-}$. When $\mathrm{NO}_{2}^{-}$concentration is comparable with $K_{\mathrm{D}}$, its significant part is complexed with ferric iron and, in consequence, the reaction with hydrogen peroxide is blocked and enzyme becomes inactivated. Thus the observed deviations from linearity in the plot of the reaction rate for substrate oxidation vs $\left[\mathrm{NO}_{2}^{-}\right]$, observed for nitrite concentrations above $2.5-5 \mathrm{mmol} \mathrm{dm}^{-3}$ (Fig. 2), is most probably connected with partial enzyme inactivation caused by nitrite binding to the ferric iron. 
It has been shown that nitrite is able to inhibit catalase activity. In the presence of 1 mmol dm ${ }^{-3}$ nitrite, at $\mathrm{pH} 7.0$, only $23 \%$ of the initial activity (the rate of $\mathrm{H}_{2} \mathrm{O}_{2}$ decomposition) was detected $\left(\left[\mathrm{H}_{2} \mathrm{O}_{2}\right]\right.$ used at this experiment was $10.5 \mathrm{mmol} \mathrm{dm}^{-3}$ ) [11]. The mechanism of this inhibition is not clear. The rate constant for the reaction of compound I of catalase with nitrite and with $\mathrm{H}_{2} \mathrm{O}_{2}$ is of the order of $10^{3} \mathrm{~mol}^{-1} \mathrm{dm}^{3} \mathrm{~s}^{-1}$ at $\mathrm{pH} 7.0[7,32]$ and of $10^{7} \mathrm{~mol}^{-1} \mathrm{dm}^{3} \mathrm{~s}^{-1}$ [33], respectively. Thus, the observed inhibition could not be due to the competition between nitrite and $\mathrm{H}_{2} \mathrm{O}_{2}$ for compound I, but was rather due to the modification of enzyme caused by nitrite.

\section{CONCLUSIONS}

Nitrite reacts with lactoperoxidase with a rate constant comparable with those for typical peroxidase substrates at $\mathrm{pH}$ 7.0. The intermediate, most probably ${ }^{\circ} \mathrm{NO}_{2}$, does not inactivate the enzyme but may react with LPO substrates at a rate even higher than that of LPO compound II with substrates. As a result, oxidation of substrates in the presence of nitrite may occur faster. When nitrite concentration exceeds 2.5-5 $\mathrm{mmol} \mathrm{dm}^{-3}$, partial enzyme inactivation is observed. On the other hand, the rate constants for the reaction of HRP compounds I and II with nitrite at neutral $\mathrm{pH}$ are much lower than those for typical HRP substrates and, in most cases, nitrite does not compete with the latter in the catalytic process.

\section{R E F E R E N C ES}

1. Dunford, H.B. (1999) Heme Peroxidases, Viley-VCH, NY, Chichester, Weinheim, Brisbane, Singapore, Toronto.

2. Grisham, M.B., Jour'heuil, D. \& Wink, D.A. (1999) Nitric oxide. I. Physiological chemistry of nitric oxide and its metabolites: Implica- tions in inflamation. Am. J. Physiol 276, G315-G321.

3. van der Vliet, A., Eiserich, J.B., Halliwell, B. \& Cross, C.E. (1997) Formation of reactive nitrogen species during peroxidase-catalyzed oxidation of nitrite. J. Biol. Chem. 272, 7617-7625.

4. Grisham, M.B., Johnson, G.G. \& Lancaster, J.R., Jr. (1996) Quantitation of nitrate and nitrite in extracellular fluids. Methods Enzymol. 268, 237-246.

5. Uppu, R.M., Squadrito, G.L., Cueto, R. \& Pryor, W.A. (1996) Selecting the most appropriate synthesis of peroxynitrite. Methods Enzymol. 269, 285-295.

6. Doyle, M.P., Herman, J.G. \& Dykstra, R.L. (1985) Autocatalytic oxidation of hemoglobin induced by nitrite: Activation and chemical inhibition. Free Radic. Biol. Med. 1, 145-153.

7. Chance, B. (1950) On the reaction of catalase peroxides with acceptors. J. Biol. Chem. 182, 649-658.

8. Chance, B. (1952) Catalase and peroxides. II. The kinetic and stechiometry of the transition from primary to the secondary peroxidase complexes. Arch. Biochem. Biophys. 41, 416-424.

9. Roman, R. \& Dunford, H.B. (1973) Studies on horseradish peroxidase. XII. A kinetic study of the oxidation of sulfite and nitrite by compounds I and II. Can. J. Chem. 51, 588-596.

10. Shibata, H., Kono,Y., Yamashita, S., Sawa, Y., Ochiai, H. \& Tanaka, K. (1995) Degradation of chlorophyll by nitrogen dioxide generated from nitrite by the peroxidase reaction. Biochim. Biophys. Acta 1239, 45-50.

11. Uppu, R.M., Squadrito, G.L., Cueto, R. \& Pryor, W.A. (1996) Synthesis of peroxynitrite by azide-ozone reaction. Methods Enzymol. 269, 311-321.

12. Klebanoff, S.J. (1993) Reactive nitrogen intermediates and antimicrobial activity: Role of nitrite. Free Radic. Biol. Med. 14, 351-360. 
13. Sampson, J.B., Ye, Y., Rosen, H. \& Beckman, J.S. (1998) Myeloperoxidase and horseradish peroxidase catalyze tyrosine nitration in proteins from nitrite and hydrogen peroxide. Arch. Biochem. Biophys. 356, 207-221.

14. Reszka, K.J., Matuszak, Z. \& Chignell, C.F. (1998) Lactoperoxidase-catalyzed oxidation of melanin by reactive nitrogen species derived from nitrite $\left(\mathrm{NO}_{2}^{-}\right)$: An EPR study. Free Radic. Biol. Med. 25, 208-216.

15. Reszka, K.J., Matuszak, Z., Chignell, C.F. \& Dillon, J. (1999) Oxidation of biological electron donors and antioxidants by a reactive lactoperoxidase metabolite from nitrite $\left(\mathrm{NO}_{2}^{-}\right)$: An EPR and spin trapping study. Free Radic. Biol. Med. 26, 669-678.

16. Reszka, K.J., Matuszak, Z. \& Chignell, C.F. (1997) Lactoperoxidase-catalyzed oxidation of the anticancer agent mitoxantrone by nitrogen dioxide $\left(\mathrm{NO}_{2}{ }^{\circ}\right)$ radicals. Chem. Res. Toxicol. 10, 1325-1330.

17. Ohlsson, P.J. \& Paul, K.G. (1976) The molar absorptivity of horseradish peroxidase. Acta Chem. Scand. B30, 373-375.

18. Carlstrom, A. (1969) Lactoperoxidase. Some spectral properties of a haemoglobin with a prosthetic group of unknown structure. Acta Chem. Scand. 23, 203-213.

19. Modi, S., Behere, D.V. \& Mitra, S. (1989) Binding of aromatic donor molecules to lactoperoxidase: Proton NMR and optical difference spectroscopic studies. Biochim. Biophys. Acta 996, 214-225.

20. Courtin, F., Michot, J.-L., Virion, A., Pommier, J. \& Deme, D. (1984) Reduction of lactoperoxidase $\mathrm{H}_{2} \mathrm{O}_{2}$ compounds by ferrocyanide: Indirect evidence of an apoprotein site for one of the two oxidizing equivalents. Biochem. Biophys. Res. Commun. 121, 463-470.

21. Doerge, D.R. \& Divi, R.L. (1995) Porphyrin $\pi$-cation and protein radicals in peroxidase catalysis and inhibition and anti-thyroid chemicals. Xenobiotica 25, 761-767.
22. Young, L.J. \& Siegel, L.M. (1988) On the reaction of ferric heme proteins with nitrite and sulfite. Biochemistry 27, 2790-2800.

23.Ferrari, R.P., Laurenti, E., Cecchini, P.I., Gambino, O. \& Sondergaard, I. (1995) Spectroscopic investigations on the highly purified lactoperoxidase $\mathrm{Fe}$ (III)-heme catalytic site. $J$. Inorg. Chem. 58, 109-127.

24. Ferrari, R.P., Ghibaudi, E.M., Traversa, S., Laurenti, E., de Gioia, L. \& Salmona, M. (1997) Spectroscopic and binding studies on the interaction of inorganic anions with lactoperoxidase. J. Inorg. Biochem. 68, 17-26.

25. Kimura, S. \& Yamazaki, J. (1979) Comparison between hog intestinal peroxidase and bovine lactoperoxidase-Compound I formation and inhibition by benzhydroxamic acid. Arch. Biochem. Biophys. 198, 580-588.

26. Metodiewa, D. \& Dunford, B.H. (1991) 3-Aminotriazole is a substrate for lactoperoxidase but not for catalase. Biochem. Biophys. Res. Commun. 180, 585-590.

27. Pruitt, K.M. \& Tenovuo, J. (1982) Kinetics of hypothiocyanite production during peroxidase-catalyzed oxidation of thiocyanate. Biochim. Biophys. Acta 704, 204-214.

28. Wever, R., Kast, W.M., Kasinoedin, J.H. \& Boelens, R. (1982) The peroxidation of thiocyanate catalyzed by myeloperoxidase and lactoperoxidase. Biochim. Biophys. Acta 709, 212-219.

29. Pruitt, K.M., Mansson-Rahemtulla, B., Baldone, D.C. \& Rahemtulla, F. (1988) Steadystate kinetics of thiocyanate oxidation catalyzed by human salivary peroxidase. Biochem. istry 27, 240-245.

30. Modi, S., Behere, D.V. \& Mitra, S. (1989) Binding of thiocyanate to lactoperoxidase: ${ }^{1} \mathrm{H}$ and ${ }^{15} \mathrm{~N}$ nuclear magnetic resonance studies. Biochemistry 28, 4689-4694.

31. Neta, P., Huie, R.E. \& Ross, A.B. (1988) Rate constants for reactions of inorganic radicals in 
aqueous solution. J. Phys. Chem. Ref. Data 17, 1112-1115.

32. Modi, S. \& Behere, D.V. (1997) Kinetic studies on oxidation of aromatic donor molecules by horseradish peroxidase and lactoperoxidase. BioMetals 10, 23-26.
33. Chance, B. (1950) The enzyme-substrate compounds of bacterial catalase and peroxides. Biochem. J. 46, 402-414.

34. Chance, B., Sies, H. \& Boveris, A. (1979) Hydroperoxide metabolism in mammalian organs. Physiol. Rev. 59, 527-605. 